\title{
Influence of Raindrop Size Distribution on Throughfall Dynamics under Pine and Birch Trees at the Rainfall Event Level
}

\author{
Katarina Zabret ${ }^{1}$ (D), Jože Rakovec ${ }^{2}$, Matjaž Mikoš ${ }^{1}$ and Mojca Šraj ${ }^{1, *}$ \\ 1 Faculty of Civil and Geodetic Engineering, University of Ljubljana, Jamova 2, SI-1000 Ljubljana, Slovenia; \\ katarina.zabret@fgg.uni-lj.si (K.Z.); matjaz.mikos@fgg.uni-lj.si (M.M.) \\ 2 Faculty of Mathematics and Physics, University of Ljubljana, Jadranska 19, SI-1000 Ljubljana, Slovenia; \\ joze.rakovec@fmf.uni-lj.si \\ * Correspondence: mojca.sraj@fgg.uni-lj.si; Tel.: +386-1-425-40-52
}

Received: 12 October 2017; Accepted: 30 November 2017; Published: 2 December 2017

\begin{abstract}
Part of precipitation is intercepted by forest canopies, while the rest reaches the ground as throughfall or stemflow. This process is influenced by various meteorological variables, of which we have mainly focused on drop diameter and velocity. Rainfall in the open and throughfall under birch and pine trees have both been measured since 2014 in Ljubljana, Slovenia. The results demonstrate that the total throughfall during 3.5 years was $73 \%$ and $53 \%$ of rainfall under birch and pine trees, respectively. During the 236 analysed events, the median volume diameter was $1.8 \mathrm{~mm}( \pm 1.7 \mathrm{~mm})$, and kinetic energy between $0.01 \mathrm{~mJ} / \mathrm{cm}^{2}$ and $23.3 \mathrm{~mJ} / \mathrm{cm}^{2}$ was recorded. We closely analysed the effect of rainfall microstructure on throughfall under pine and birch trees during three specific rainfall events. The increase in drop diameter and fall velocity during a rainfall event instantaneously increased throughfall under pine trees between $25 \%$ and $47 \%$, whereas no such changes were observed under birch trees. This may be the consequence of different tree properties of the two species. Additionally, in the case of a saturated canopy, throughfall under pine trees exceeded rainfall in the open after an onset of larger and faster drops.
\end{abstract}

Keywords: rainfall; rainfall interception; throughfall; raindrop size distribution; drop velocity; birch; pine; Slovenia

\section{Introduction}

Rainfall interception can be observed when precipitation falls above ground that is covered with vegetation. When rainfall reaches the tree canopy, some raindrops fall directly through the gaps in the canopy, while the rest are retained on leaves and branches. Drops retained in the canopy can later reach the ground by dripping, or can evaporate back into the atmosphere. The latter is known as rainfall interception or interception loss. The precipitation can reach the ground by flowing down the branches and stems (i.e., stemflow), or by falling through or from the canopy (i.e., throughfall).

Throughfall itself consists of three components: free throughfall, drip, and splash [1-4]. Free throughfall falls directly through the gaps in the tree canopy, has no contact with leaves or branches, and maintains the drop size distribution of an open rainfall [1]. Dripping describes rainfall drops captured in the canopy that fall to the floor mainly due to saturation of the canopy, while splash describes drops falling from the canopy due to external influences such as wind or rainfall [5]. Throughfall splash droplets are usually smaller than drops induced by dripping. Most often, a throughfall drop diameter of $1.5 \mathrm{~mm}$ has been measured as the threshold value determining a specific throughfall component, as smaller drops are splash-induced and larger drops are generated by dripping $[3,6]$. 
The amount of throughfall is influenced by various variables. In general, they can be divided into vegetation or meteorological variables. Some of the vegetation variables are phenophase, canopy storage capacity, bark structure, leaf area index (LAI), stem diameter at breast height (DBH), and projected canopy area, [7-10]. Meteorological variables are, among others, the amount of rainfall, the duration of a rainfall event, rainfall intensity, wind velocity and direction, air temperature, humidity, and the properties of raindrops [11-15].

Raindrop properties, deffined by drop diameter and velocity, are used to describe the discrete nature of precipitation, which is often neglected in research connected with rainfall [16]. The most important processes influenced by drop size distribution (DSD) are rainfall interception by vegetation canopies [3-6,17-19] and soil erosion through raindrop impact [20-22].

The processes of rainfall interception, throughfall, and stemflow depend on the various properties of raindrops [17,18]. The focus of past studies has been mainly on the investigation of throughfall DSD under trees [5]. Throughfall has different DSDs under canopies of various tree species [3], because the drips from different types of leaves or needles produce different throughfall DSDs [23]. Splash and storage from leaves depend also on drop diameter of rainfall in the open and on leaf inclination [4]. Additionally, throughfall drops are smaller under severe canopy vibrations, due to the high wind speed and high rainfall intensity [3]. Throughfall drop characteristics-maximum diameter and median volume diameter-are also smaller when the canopy is foliated, as the phenophase is one of the most significant variables influencing throughfall DSD [6].

However, the DSD of the rainfall in the open was rarely taken into account in earlier studies of rainfall partitioning (interception, throughfall, and stemflow). During the development of a stochastic interception model, Calder [17] showed that the wetting of the canopies depends on the volume of the individual raindrops, as small raindrops increase the amount of water retained in the canopy. The influence of raindrop size on the predicted interception amount was also observed by Hall [18]. Open rainfall DSDs were measured by Zabret et al. [24], who showed that during a single event, an increase in drop diameter immediately increased throughfall under pine trees, which can, under specific conditions, exceed the amount of rainfall in the open.

The microstructure of rainfall varies in time and in space, and differs from event to event. It significantly influences parts of the hydrological cycle, yet it is often overlooked [16]. Its influence on rainfall partitioning has been mainly analysed from the soil erosion perspective, in studies generally focused on throughfall DSD. Therefore, the main objectives of this study are as follows: (i) to analyse the influence of drop diameter and velocity of open rainfall on the amount of throughfall, (ii) to evaluate this influence for two tree species (i.e., birch and pine), and (iii) to evaluate this influence on rainfall events with different properties (e.g., rainfall amount, intensity).

\section{Methods}

\subsection{Description of the Experimental Setup}

The measurements were taken in the City of Ljubljana, Slovenia. The experimental site is located in the city's urban area $\left(46.04^{\circ} \mathrm{N}, 14.49^{\circ} \mathrm{E}\right)$ at $292 \mathrm{~m}$ above sea level. The climate is subalpine, with maritime influences from the Mediterranean and subcontinental influences from the Pannonian Plain. The average long-term (1986-2016) annual temperature is $11^{\circ} \mathrm{C}$, with the average monthly temperature ranging from $-3{ }^{\circ} \mathrm{C}$ to $24^{\circ} \mathrm{C}$. The average annual rainfall amount is $1380 \mathrm{~mm}$, with the maximum monthly precipitation mainly recorded in autumn, with a mean monthly value of $146 \mathrm{~mm}$ [25].

The experimental site is flat and covers approximately $600 \mathrm{~m}^{2}$. Two groups of trees grow in the western part of the site (Figure 1). Throughfall and stemflow were measured under native tree species, commonly found in Slovenia: two black pines (Pinus nigra) and two birch trees (Betula pendula) (Table 1). In the eastern part of the experimental site, where regularly-cut grass prevailed, rainfall in the open (non-sheltered location) was measured. Drop size and velocity were measured on the rooftop of a nearby two-storey building. 


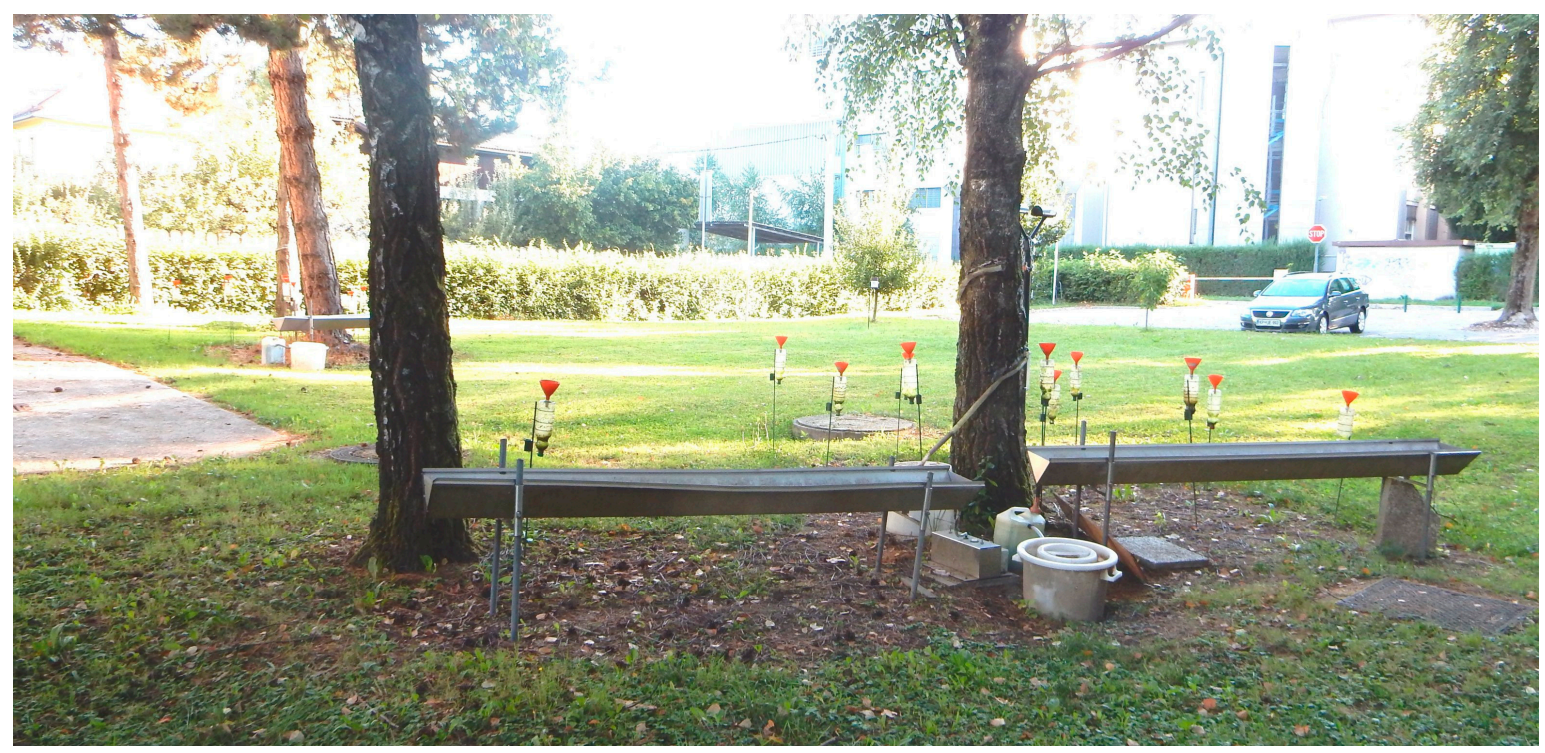

Figure 1. Experimental setup under the birch trees.

Table 1. Properties of the trees in the experimental setup.

\begin{tabular}{|c|c|c|c|c|c|c|}
\hline $\begin{array}{c}\text { Tree } \\
\text { Species }\end{array}$ & $\begin{array}{l}\text { Average } \\
\text { Height }[\mathrm{m}]\end{array}$ & $\begin{array}{c}\text { Average } \\
\text { DBH }^{1}[\mathrm{~cm}]\end{array}$ & $\begin{array}{c}\text { Total Projected } \\
\text { Crown Area }\left[\mathrm{m}^{2}\right]\end{array}$ & $\begin{array}{l}\text { Average Branch } \\
\text { Inclination }^{2}\end{array}$ & $\begin{array}{c}\text { LAI }^{3} \\
\text { (Leafed Period) }\end{array}$ & $\begin{array}{c}\text { Bark } \\
\text { Characteristics }\end{array}$ \\
\hline Birch & $15.7( \pm 1.0)$ & $17.9( \pm 0.4)$ & 42.3 & $51^{\circ}$ & 4.72 & Thin, smooth \\
\hline Pine & $12.6( \pm 0.6)$ & $19.0( \pm 2.3)$ & 22.7 & $98^{\circ}$ & 1.8 & Thick, rough \\
\hline
\end{tabular}

${ }^{1} \mathrm{DBH}$ - diameter at breast height; ${ }^{2}$ Average branch inclination of all main branches growing from the stem (from stem to branch); ${ }^{3} \mathrm{LAI}$ - leaf area index.

\subsection{Measurements}

Precipitation in the open area was measured using a tipping bucket $\left(0.2 \mathrm{~mm} / \mathrm{tip}, 0.03 \mathrm{~m}^{2}\right.$ area) rain gauge (Onset RG2-M) with an automatic data logger (Onset HOBO Event), positioned $1 \mathrm{~m}$ above the ground. The rain gauge was positioned in the clearing at the experimental site. Near the experimental site, there was a two-storey building, on the rooftop of which we placed the OTT Parsivel optical disdrometer. The distance between the disdrometer and the trees $(45 \mathrm{~m})$ was short enough that drop size distribution (DSD) measured by the disdrometer was also representative of the DSD at the trees' location [26]. Additionally, the height of the rooftop $(14.45 \mathrm{~m})$ was approximately the same as the height of the tree canopies. The disdrometer's measuring area was $54 \mathrm{~cm}^{2}$. The measured data were allocated to one of the 32 drop diameter classes (i.e., between $0.312 \mathrm{~mm}$ and $24.5 \mathrm{~mm}$ ) and velocity classes (i.e., between $0.05 \mathrm{~m} / \mathrm{s}$ and $20.8 \mathrm{~m} / \mathrm{s}$ ), average values of which were used in the data analysis (Table 2). Drop diameters smaller than $0.312 \mathrm{~mm}$ were not classified in separate classes, as they were outside of the device's measurement range. Therefore, the number of smaller rain drops has been classified in the smallest drop diameter class $(0.312 \mathrm{~mm})$. We have to emphasise that the DSD measurements in this study were taken using the OTT Parsivel optical disdrometer, as DSD evaluations can slightly differ from one instrument to another, e.g., OTT Parsivel, POSS, LPM300 and 2DVD, on which the interpretation of the data depends as well $[21,27,28]$.

Throughfall has been measured under four trees (two pine and two birch trees) for three and a half years. Under each of the selected tree species, various methods of throughfall measurements were implemented, in order to catch the spatial variability of throughfall, and to avoid missing data. Throughfall is best measured using a combination of fixed and roving gauges to ensure representative samples $[14,29,30]$. Two steel trough gauges $\left(0.75 \mathrm{~m}^{2}\right.$ area) were positioned alongside each tree stem towards the tree canopy edge (Figure 1). Under each of the tree species, one trough gauge was equipped 
with a tipping bucket flow gauge $(0.19 \mathrm{~mm} /$ tip, Unidata $6506 \mathrm{G})$ and an automatic data logger (Onset HOBO Event). The data from the other trough gauge, connected to polyethylene 10-L containers attached to a 50-L polyethylene barrel, were collected manually after each rainfall event. Additionally, ten roving manually-read gauges with funnels $0.1 \mathrm{~m}$ in diameter $\left(0.008 \mathrm{~m}^{2}\right.$ area $)$, connected to $1 \mathrm{~L}$ bottles, were randomly placed underneath each tree.

Stemflow was measured for one tree of each species. A rubber collar was halved and spirally wrapped around the stem, attached with nails and silicone. The lower part of the hose was connected to a 20-L manually-read polyethylene container, which was emptied at the same time as the throughfall gauges.

Table 2. The size and velocity classes of the raindrops identified by the OTT Parsivel disdrometer [31].

\begin{tabular}{|c|c|c|c|c|c|}
\hline \multicolumn{3}{|c|}{ Raindrop Diameter Classes } & \multicolumn{3}{|c|}{ Raindrop Velocity Classes } \\
\hline $\begin{array}{l}\text { Average Class } \\
\text { Value }[\mathrm{mm}]\end{array}$ & $\begin{array}{l}\text { Lower Limit } \\
{[\mathrm{mm}]}\end{array}$ & $\begin{array}{l}\text { Upper Limit } \\
{[\mathrm{mm}]}\end{array}$ & $\begin{array}{l}\text { Average Class } \\
\text { Value }[\mathrm{m} / \mathrm{s}]\end{array}$ & $\begin{array}{l}\text { Lower Limit } \\
{[\mathrm{m} / \mathrm{s}]}\end{array}$ & $\begin{array}{l}\text { Upper Limit } \\
{[\mathrm{m} / \mathrm{s}]}\end{array}$ \\
\hline & & & 0.05 & 0 & 0.1 \\
\hline & & & 0.15 & 0.1 & 0.2 \\
\hline 0.312 & 0.2495 & 0.3745 & 0.25 & 0.2 & 0.3 \\
\hline 0.437 & 0.3745 & 0.4995 & 0.35 & 0.3 & 0.4 \\
\hline 0.562 & 0.4995 & 0.6245 & 0.45 & 0.4 & 0.5 \\
\hline 0.687 & 0.6245 & 0.7495 & 0.55 & 0.5 & 0.6 \\
\hline 0.812 & 0.7495 & 0.8745 & 0.65 & 0.6 & 0.7 \\
\hline 0.937 & 0.8745 & 0.9995 & 0.75 & 0.7 & 0.8 \\
\hline 1.062 & 0.9995 & 1.1245 & 0.85 & 0.8 & 0.9 \\
\hline 1.187 & 1.1245 & 1.25 & 0.95 & 0.9 & 1 \\
\hline 1.375 & 1.25 & 1.5 & 1.1 & 1 & 1.2 \\
\hline 1.625 & 1.5 & 1.75 & 1.3 & 1.2 & 1.4 \\
\hline 1.875 & 1.75 & 2 & 1.5 & 1.4 & 1.6 \\
\hline 2.125 & 2 & 2.25 & 1.7 & 1.6 & 1.8 \\
\hline 2.375 & 2.25 & 2.5 & 1.9 & 1.8 & 2 \\
\hline 2.75 & 2.5 & 3 & 2.2 & 2 & 2.4 \\
\hline 3.25 & 3 & 3.5 & 2.6 & 2.4 & 2.8 \\
\hline 3.75 & 3.5 & 4 & 3 & 2.8 & 3.2 \\
\hline 4.25 & 4 & 4.5 & 3.4 & 3.2 & 3.6 \\
\hline 4.75 & 4.5 & 5 & 3.8 & 3.6 & 4 \\
\hline 5.5 & 5 & 6 & 4.4 & 4 & 4.8 \\
\hline 6.5 & 6 & 7 & 5.2 & 4.8 & 5.6 \\
\hline 7.5 & 7 & 8 & 6 & 5.6 & 6.4 \\
\hline 8.5 & 8 & 9 & 6.8 & 6.4 & 7.2 \\
\hline 9.5 & 9 & 10 & 7.6 & 7.2 & 8 \\
\hline 11 & 10 & 12 & 8.8 & 8 & 9.6 \\
\hline 13 & 12 & 14 & 10.4 & 9.6 & 11.2 \\
\hline 15 & 14 & 16 & 12 & 11.2 & 12.8 \\
\hline 17 & 16 & 18 & 13.6 & 12.8 & 14.4 \\
\hline 19 & 18 & 20 & 15.2 & 14.4 & 16 \\
\hline 21.5 & 20 & 23 & 17.6 & 16 & 19.2 \\
\hline 24.5 & 23 & 26 & 20.8 & 19.2 & 22.4 \\
\hline
\end{tabular}

\subsection{Data Analysis Methods}

Each rainfall event was defined based on the time gap between the end of the previous and the beginning of the next rainfall event. At least a 4-h dry period between the events was defined, based on our observations of the time in which the canopy could dry out. For each event, the number of drops, their diameter, and their velocity were obtained from the disdrometer's raw data. The event's median volume diameter (D50) [6], rainfall kinetic energy [32,33], and the number of raindrops per event were calculated according to disdrometer's measuring area $\left(54 \mathrm{~cm}^{2}\right)$. The velocity spectrum is largely redundant with the size spectrum, as drop terminal velocity depends on its size $(v=v(D))$. 
Gunn and Kinzer [34] showed that the velocity of drops with diameters less than $0.3 \mathrm{~mm}$ depends rather linearly on diameter, and that the velocity of drops with diameters larger than $0.3 \mathrm{~mm}$ depends on the square root of the diameter.

Throughfall per event was corrected using measured values from both the through and the funnel gauges, according to their area. Stemflow was calculated based on the projected area of the corresponding tree canopy [35]. Rainfall interception (I) was defined based on a simple water balance equation, using measured precipitation (P), throughfall (TF), and stemflow (SF) e.g., [36]:

$$
\mathrm{I}=\mathrm{P}-\mathrm{TF}-\mathrm{SF}
$$

Data analyses were performed using $\mathrm{R}$, a software environment for statistical computing and graphics [37].

\section{Results}

Rainfall, throughfall, and stemflow were measured from 1 January 2014 to 30 June 2017. Snow events were excluded. During this period, 413 rainfall events were observed, with a total of $4110.8 \mathrm{~mm}$ of rainfall, an average rainfall amount per event of $9.9 \mathrm{~mm}$ (ranging between $0.2 \mathrm{~mm}$ and $167.4 \mathrm{~mm}$ ), and an average rainfall duration of $8.5 \mathrm{~h}$ (ranging between $6 \mathrm{~min}$ and $119 \mathrm{~h}$ ). In a further analysis, we took into account 236 rainfall events for which complete data on drop diameter and velocity were available. During these events, $2517.1 \mathrm{~mm}$ of rainfall was measured, with an average rainfall amount per event of $10.7 \mathrm{~mm}$ (ranging between $0.2 \mathrm{~mm}$ and $93 \mathrm{~mm}$ ), and an average rainfall duration of $8.3 \mathrm{~h}$ (ranging between $6 \mathrm{~min}$ and $67 \mathrm{~h}$ ).

\subsection{Throughfall, Stemflow, and Rainfall Interception}

The throughfall measured under the birch trees was, on average, $55 \%( \pm 30 \%)$ of gross rainfall per single event, and in total accounted for $1828.5 \mathrm{~mm}(73 \%)$ of rainfall during the entire observation period (Figure 2). Under the pine trees, $29 \%$ ( $\pm 26 \%$ ) of throughfall was observed on average per single event, which in total resulted in $1337.2 \mathrm{~mm}(53 \%)$ of rainfall during three and a half years. Stemflow was much lower than throughfall (Figure 2). In total, stemflow for the birch tree was $82.4 \mathrm{~mm}(3.3 \%$ of rainfall), while for the pine tree it was negligible at $1.6 \mathrm{~mm}$ ( $0.06 \%$ of rainfall). Stemflow was observed during 134 events in the case of the birch tree, and ranged between $0.001 \mathrm{~mm}$ and $4.61 \mathrm{~mm}$. Under the pine tree, stemflow was detected during 102 rainfall events; however, the single event amounts ranged up to $0.12 \mathrm{~mm}$ only. Rainfall interception by the birch trees was, on average, $43 \%$ ( $\pm 31 \%$ ) per event, while the pines intercepted, on average, $71 \%( \pm 26 \%)$ per event (Figure 2$)$. In three events, the birch trees did not intercept any rainfall; in the case of the pine trees, however, at least minimal interception was always observed. 

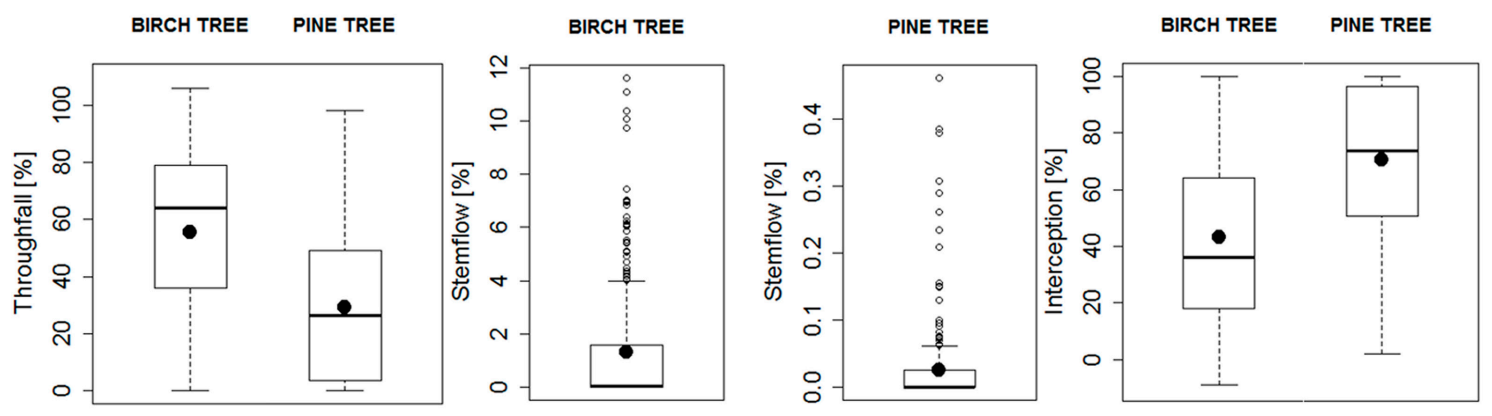

BIRCH TREE

leafed period leafless period

leafed period leafless period
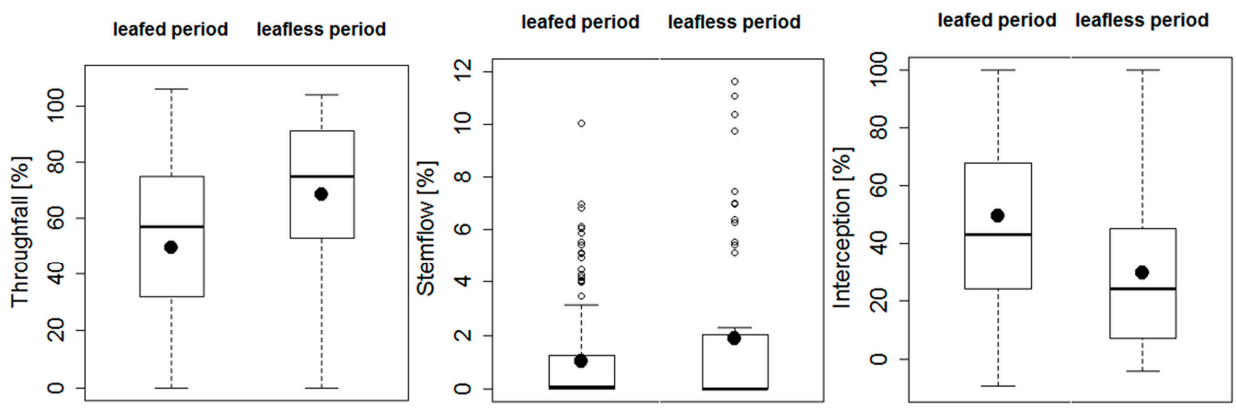

Figure 2. Box-and-whisker plots of throughfall, stemflow, and rainfall interception under birch and pine trees (note the different scale for stemflow), and under the birch tree during two vegetation periods. The black point inside the box represents the mean value, the black bold line represents the median value, and the box height includes the upper and the lower quartile values, while the bars represents the highest and the lowest values. The outliers are presented with individual points outside the box limits.

\subsection{Number of Raindrops, Their Median Volume Diameter, and Kinetic Energy}

The number of raindrops per event varied between 6 and 13,478 per $\mathrm{cm}^{2}$. Fewer than 19 drops per $\mathrm{cm}^{2}$ were detected in six events, all of which delivered less than $0.6 \mathrm{~mm}$ of rainfall. The maximum number of raindrops was observed during a three-day event in November 2016, with $84.4 \mathrm{~mm}$ of rainfall. On average, 1578 raindrops per $\mathrm{cm}^{2}$ were observed for the analysed 236 rainfall events.

Median volume diameters (D50) were, on average, $1.8 \mathrm{~mm}( \pm 1.7 \mathrm{~mm})$, varying between $0.4 \mathrm{~mm}$ and $4.4 \mathrm{~mm}$. The kinetic energy of the rainfall events ranged from $0.01 \mathrm{~mJ} / \mathrm{cm}^{2}$ to $23.3 \mathrm{~mJ} / \mathrm{cm}^{2}$, and was on average equal to $2.1 \mathrm{~mJ} / \mathrm{cm}^{2}$.

\subsection{Effect of Drop Diameter and Velocity on Throughfall}

The effect of raindrop size and velocity on throughfall under birch and pine trees was evaluated in more detail for three selected rainfall events, i.e., on 22 May 2017, 26 June 2016 and 21 August 2016 (Table 3). Firstly, the events with incomplete temporal data from any of the gauges (rain gauge, disdrometer, automatic through gauges under birch and pine trees) were eliminated. Among the events with complete data, these three events from the foliated period were selected, representing an average extension of rainfall amount and intensity for all of the 236 measured events. Furthermore, the duration of each of the selected rainfall events was similar, in order to eliminate its influence. The throughfall used for the analysis was measured by the automatic through gauge, which was placed from the tree trunk towards the edge of the canopy, and reflected an average spatial variability of throughfall. 
Table 3. Properties of the selected rainfall events and corresponding throughfall (TF).

\begin{tabular}{ccccccccc}
\hline Event & $\begin{array}{c}\text { Duration } \\
{[\mathrm{min}]}\end{array}$ & $\begin{array}{c}\text { Rainfall } \\
\text { Amount }[\mathrm{mm}]\end{array}$ & $\begin{array}{c}\text { Rainfall Intensity } \\
{[\mathrm{mm} / \mathbf{h}]}\end{array}$ & $\begin{array}{c}\text { Average Wind } \\
\text { Speed }[\mathrm{m} / \mathbf{s}]\end{array}$ & $\begin{array}{c}\text { TF } \\
\text { Birch }\end{array}$ & $\begin{array}{c}\text { TF } \\
\text { Pine }\end{array}$ & $\begin{array}{c}\text { Kinetic Energy } \\
{\left[\mathrm{mJ} / \mathrm{cm}^{2}\right]}\end{array}$ & $\begin{array}{c}\text { D50 } \\
{[\mathrm{mm}]}\end{array}$ \\
\hline A 22 May 2017 & 54 & 8.0 & 8.9 & 2.67 & $69 \%$ & $31 \%$ & 1.99 & 2.92 \\
B 26 June 2016 & 69 & 15.2 & 13.2 & 2.28 & $62 \%$ & $77 \%$ & 2.23 & 2.94 \\
\hline C 21 August 2016 & 71 & 33.4 & 28.2 & 2.80 & $64 \%$ & $70 \%$ & 5.12 & 2.39 \\
\hline
\end{tabular}

The weakest event A (22 May 2017) was the shortest (Table 3), with a small precipitation amount, and with continuous rainfall distribution during the middle part of the event. The distribution of drop velocity and diameter changed over time similar to rainfall distribution, namely because the intensity increased during the first $10 \mathrm{~min}$ (20:00-20:10), stayed strong through the 30th min (20:10-20:30), and then decreased (Figure 3). Two peaks in drop diameter and velocity were observed, i.e., between minutes 13 and 17 and between minutes 20 and 25 from the beginning of the event. Drop diameter reached up to $7.5 \mathrm{~mm}$, and the highest measured velocity was $12 \mathrm{~m} / \mathrm{s}$.

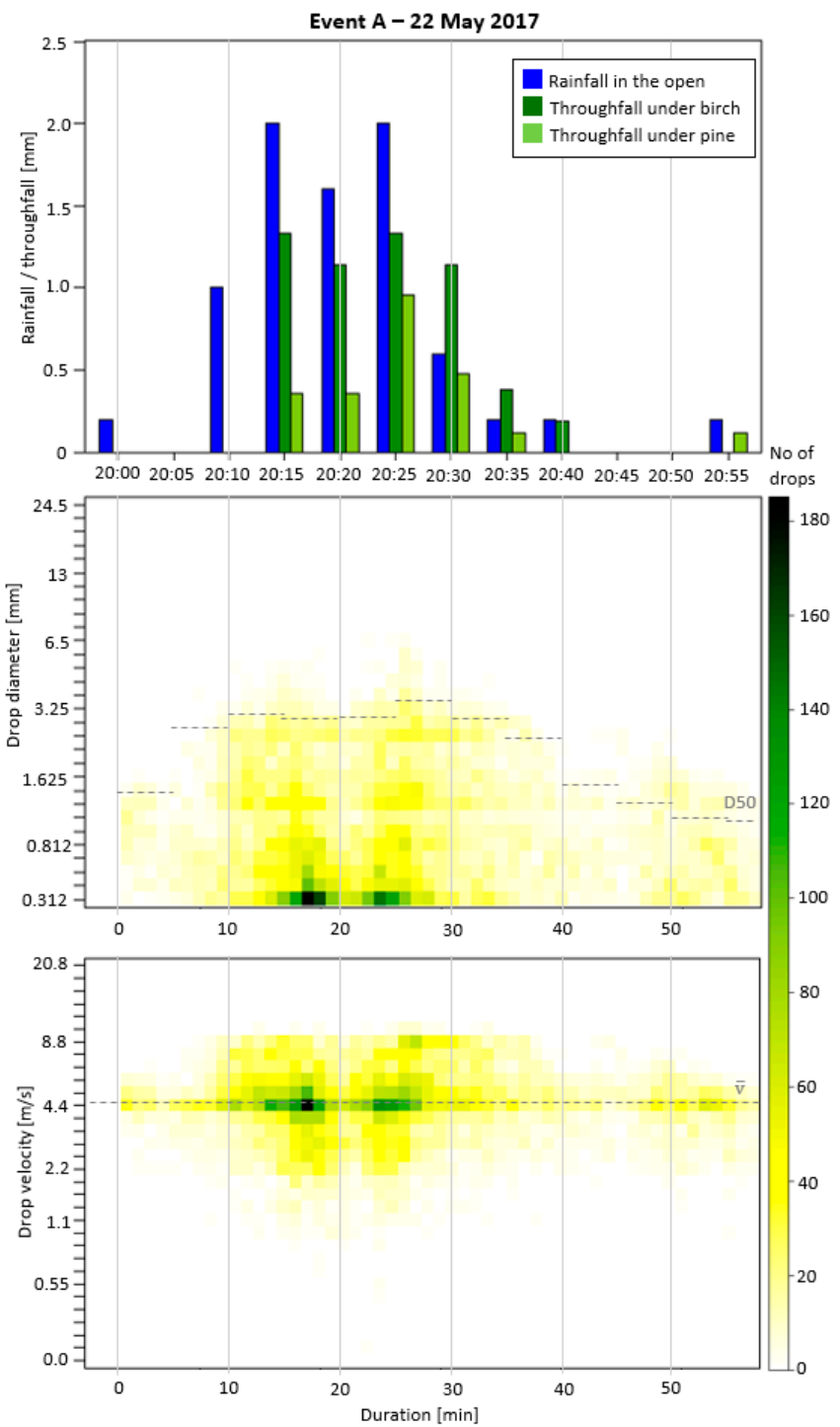

Figure 3. The weakest event A rainfall and throughfall under birch and pine trees in 5-min time intervals (upper panel), raindrop diameter (middle panel), and velocity in 1-min time intervals (bottom panel). The dashed line indicates median volume diameter (D50) and average velocity $(\bar{v})$. Number of drops represents raw data. 
Throughfall under the pine trees started after $15 \mathrm{~min}$ (20:15) from the beginning of the event, when raindrop diameter and velocity increased for the first time. Throughfall immediately accounted for $23 \%$ of rainfall and, after a cloud of even larger and faster raindrops appeared, it increased up to $48 \%$ and $80 \%$ in two 5-min intervals (20:25 and 20:30), respectively (Table 4). However, throughfall under the pine trees did not exceed the rainfall in the open during the event (Figure 3). Throughfall under the birch trees similarly started after the increase in raindrop diameter and velocity (20:15). The amount of throughfall under the birch trees instantaneously reached $67 \%$ of rainfall, and remained at the same level until the significant decrease in rainfall, drop diameter, and velocity (20:35). At the same time, the amount of throughfall started to decrease, but at a slower pace than the amount of rainfall. Therefore, at that time (20:30-20:35), throughfall under the birch trees was greater than rainfall in the open (Table 4).

Table 4. Variations in rainfall intensity, raindrop median volume diameter (D50), velocity, and throughfall (TF) during three significant 5-min time steps for event A.

\begin{tabular}{cccccc}
\hline Time & Intensity [mm/5min] & D50 [mm] & Average Drop Velocity [m/s] & TF Pine [\%] & TF Birch [\%] \\
\hline $20: 25$ & 0.4 & 2.81 & 5.04 & $48 \%$ & $67 \%$ \\
$20: 30$ & 0.12 & 3.60 & 5.34 & $80 \%$ & $67 \%$ \\
20:35 & 0.04 & 2.76 & 4.94 & $60 \%$ & $190 \%$ \\
\hline
\end{tabular}
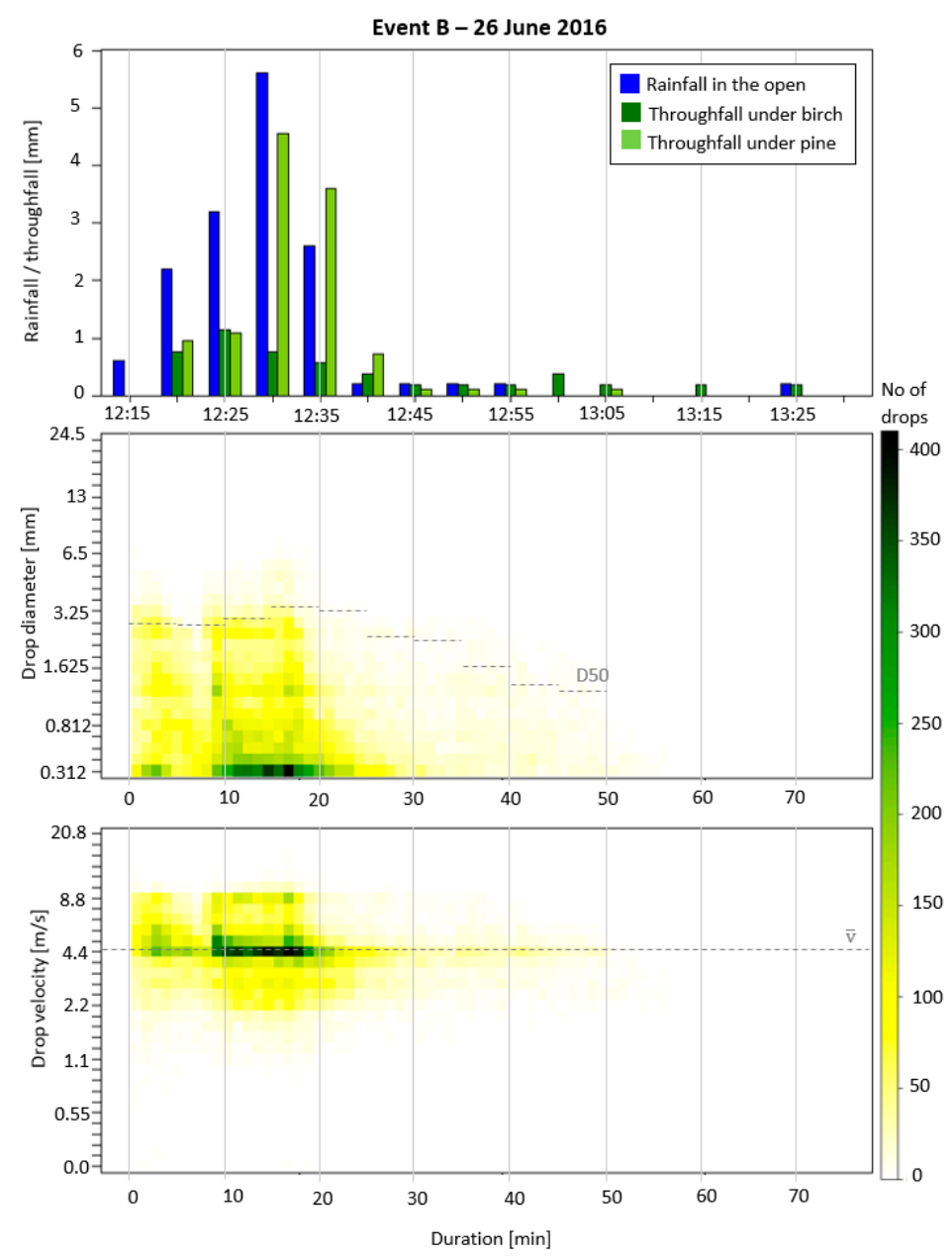

Figure 4. The medium intensity event $B$ rainfall and throughfall under birch and pine trees in 5-min time intervals (upper panel), raindrop diameter (middle panel), and velocity in 1-min time intervals (bottom panel). The dashed line indicates median volume diameter (D50) and average velocity $(\bar{v})$. Number of drops represents raw data. 
Event B (26 June 2016) (Table 3) is characterized by a concentration of rainfall at the onset of the event. In the first $30 \mathrm{~min}, 95 \%$ of total rainfall was detected. Furthermore, in the first $20 \mathrm{~min}$ the raindrops were larger and faster than during the rest of the event (Figure 4). The raindrop diameter was, on average, $1.09 \mathrm{~mm}$ and $0.78 \mathrm{~mm}$ during the first and second parts of the event, respectively, and the velocity was, on average, $4.76 \mathrm{~m} / \mathrm{s}$ and $4.11 \mathrm{~m} / \mathrm{s}$. From the event minutes 13 to 18 , an additional increase in drop diameter up to $7.5 \mathrm{~mm}$ and drop velocity up to $15.2 \mathrm{~m} / \mathrm{s}$ was observed (Figure 4).

The peak in raindrop diameter and velocity after the 13th $\min$ (at 12:30) instantaneously increased the amount of throughfall under the pine trees. In the first $5 \mathrm{~min}$, throughfall increased from $34 \%$ to $81 \%$, and in the next $5 \mathrm{~min}$ (by 12:35), it even exceeded the amount of rainfall in the open (Table 5). At the same time, no significant response was observed for throughfall under the birch trees (Figure 4). In the part of the event with declining rainfall (12:40), the throughfall under the birch trees remained approximately the same, and therefore exceeded the rainfall measured in the open (Table 5).

Table 5. Variations in rainfall intensity, raindrop median volume diameter (D50), velocity and throughfall (TF) during three significant 5-min time steps for event B.

\begin{tabular}{cccccc}
\hline Time & Intensity [mm/5min] & D50 [mm] & Average Drop Velocity [m/s] & TF Pine [\%] & TF Birch [\%] \\
\hline $12: 30$ & 1.12 & 2.70 & 4.37 & $81 \%$ & $14 \%$ \\
$12: 35$ & 0.52 & 3.47 & 4.11 & $138 \%$ & $22 \%$ \\
$12: 40$ & 0.04 & 3.35 & 4.11 & $360 \%$ & $190 \%$ \\
\hline
\end{tabular}

The strongest event $C$ (21 August 2016) was one of the most intense among all of the measured events in three and a half year period (Table 3). According to the raindrop size and velocity, the event was divided into two parts (Figure 5). In the first $20 \mathrm{~min}, 26.2 \mathrm{~mm}$ of rainfall was measured, corresponding to $78 \%$ of the total rainfall. Raindrop diameter reached up to $7.5 \mathrm{~mm}$ and was, on average, $1.06 \mathrm{~mm}$. Raindrop velocity was as high as $15.2 \mathrm{~m} / \mathrm{s}$, and on average $4.73 \mathrm{~m} / \mathrm{s}$. The highest values of both were observed within a short time interval between the 4th and 7th min from the start of the event. In the second part of the event, both drop diameter and velocity were lower, averaging $0.75 \mathrm{~mm}$ and $4.17 \mathrm{~m} / \mathrm{s}$, respectively, and reaching up to $3.75 \mathrm{~mm}$ and $10.4 \mathrm{~m} / \mathrm{s}$.

Throughfall under the pine trees started 5 min after the beginning of the event (5:00), and at that time already amounted to $51 \%$ of the rainfall. As the event progressed, throughfall increased, but it did not exceed the amount of precipitation in the open. Throughfall under the pine trees was following the trend of the rainfall, increasing in the first part and decreasing in the second part of the event (Figure 5). The response of the birch trees to the high intensity rainfall, with large and fast raindrops, was slower, as throughfall increased gradually. In the first part of the event, the throughfall accounted for only $5.9 \mathrm{~mm}(28 \%$ of total measured throughfall). However, the amount of throughfall remained the same $(3.23 \mathrm{~mm})$ for the next $15 \mathrm{~min}$ (5:15-5:30), after the decrease of rainfall, denoting the second part of the event. During the $20 \mathrm{~min}$ after this turning point (5:20-5:35), the throughfall under the birch trees was higher than the amount of rainfall in the open (Table 6). 

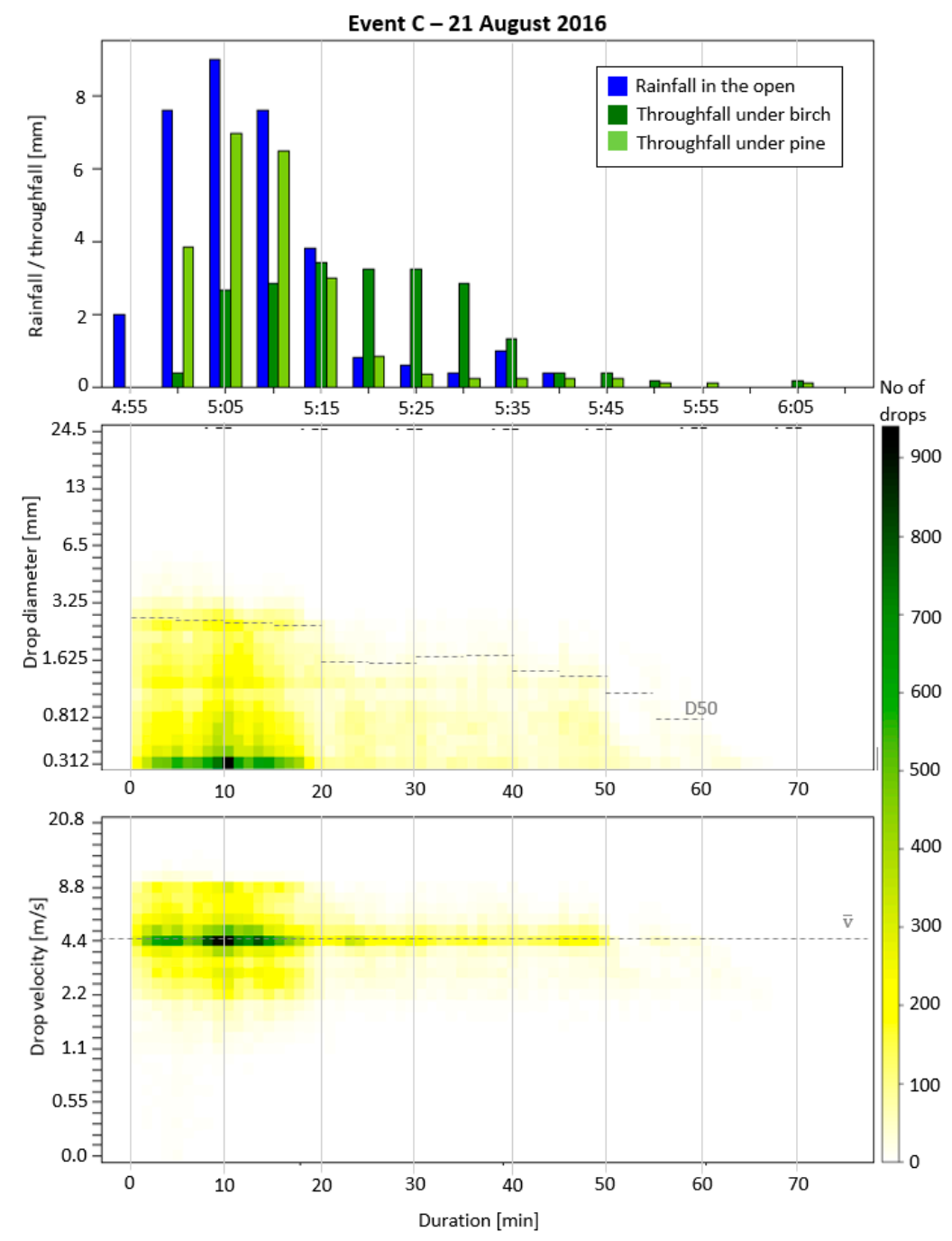

Figure 5. The strongest event $C$ rainfall and throughfall under birch and pine trees in 5-min time intervals (upper panel), raindrop diameter (middle panel), and velocity in 1-min time intervals (bottom panel). The dashed line indicates median volume diameter (D50) and average velocity $(\bar{v})$. Number of drops represents raw data.

Table 6. Variations in rainfall intensity, raindrop median volume diameter (D50), velocity and throughfall (TF) during three significant 5-min time steps for event $\mathrm{C}$.

\begin{tabular}{cccccc}
\hline Time & Intensity [mm/5min] & D50 [mm] & Average Drop Velocity [m/s] & TF Pine [\%] & TF Birch [\%] \\
\hline $5: 15$ & 0.76 & 2.31 & 4.64 & $79 \%$ & $90 \%$ \\
$5: 20$ & 0.16 & 1.53 & 4.44 & $105 \%$ & $404 \%$ \\
$5: 25$ & 0.12 & 1.45 & 4.41 & $60 \%$ & $538 \%$ \\
\hline
\end{tabular}

\section{Discussion}

The results of this study demonstrate that during 236 rainfall events, throughfall accounted for $73 \%$ and $53 \%$ of rainfall under the observed birch and pine trees, respectively (Figure 2). Similar results were reported by other researchers. Throughfall under urban deciduous trees was measured at $71 \%$ of rainfall under a blue gum tree in Melbourne, Australia [35], and 74\% of rainfall under a ginkgo tree in California, U.S. [38]. Additionally, throughfall in a residential urban forest in North Carolina, U.S., ranged between $78 \%$ and $89 \%$ of rainfall [39]. These values correspond well to the results of throughfall under the birch trees in the present study. Furthermore, the results of throughfall under 
the pine trees in this study agree with the annual proportions of throughfall ranging from $51 \%$ to $78 \%$ of rainfall in a pine forest in northern Britain [40], and with the average throughfall of $66 \%$ in red pine plantations in southern Ontario, Canada [41]. Similar values were also measured for coniferous Douglas fir trees and western red cedar trees in an urban area of British Columbia, Canada, for which throughfall resulted in $50 \%$ and $46 \%$ of rainfall, respectively [42].

For the three analysed rainfall events (Table 3), throughfall under the birch trees was lower than the average for this study (Figure 2). However, throughfall under pine trees was higher than the average value during events $B$ and $C$, and lower during event $A$. The duration of events $B$ and $C$ is almost equal, whereas event $\mathrm{A}$ was the shortest among the three considered events, and had a lower rainfall intensity (Table 3). The increase of throughfall with a longer rainfall event duration and higher rainfall intensity was also observed in other studies [11,14,15,43,44]. Additionally, the majority of rainfall was delivered at the beginning of events $B$ and $C$, whereas the rainfall during event $A$ was more evenly distributed (Figures 3-5). The high amount of rainfall at the beginning of the event resulted in a faster saturation of the tree canopy. Although drainage starts prior the complete canopy saturation, as reported by Klassen et al. [45], it increases afterwards, resulting in higher throughfall during the rest of the event. The same was demonstrated also by Andre et al. [13].

A detailed analysis of drop size distribution (DSD) demonstrates that the occurrence of larger raindrop diameters and higher drop velocities during all three events induced changes in throughfall under the pine trees (Figures 3-5). This corresponds with the findings of Calder [17], Calder et al. [46], and Hall et al. [47], which found that throughfall is higher for larger raindrop diameters. A five-min time interval with larger drop diameters and velocities was observed more than 10 min after the beginning of events $A$ and $B$. That interval increased throughfall under the pine trees by $47 \%$ and $25 \%$ during events $A$ and $B$, respectively. Larger drop size distribution during event $C$ was observed sooner, from minutes 4 to 7 , as well as increased throughfall under the pine trees by $26 \%$. A similar increase of $28 \%$ and $20 \%$ of throughfall under pine trees, after the onset of larger and faster raindrops during June and July 2014 events, respectively, was reported also by Zabret et al. [24]. On the other hand, no influence from changes in the drop size spectrum on throughfall under the birch trees was observed in this study.

Analysis of event A demonstrates that an increase in drop diameter and velocity might have started the throughfall under both species of trees. During event B, throughfall under both the birch and pine trees started after $5 \mathrm{~min}$, i.e., when $2 \mathrm{~mm}$ of rainfall had fallen. Throughfall under the pine trees was induced by $3 \mathrm{~mm}$ of rainfall, and under the birch trees by $7.8 \mathrm{~mm}$, which were measured 4 and 7 min after the beginning of event $C$, respectively. However, during event $A$, throughfall under the birch trees started 12 min after the beginning of the rainfall event, while throughfall under the pine trees started after $14 \mathrm{~min}$. At that time, the first increase in drop size spectra was observed (Figure 3). The rainfall amount needed to induce throughfall during this event was only $1.2 \mathrm{~mm}$ and $1.8 \mathrm{~mm}$ for the birch and pine trees, respectively. A similar phenomenon of inducing throughfall by a cloud of larger drops was also shown in other studies [3,24]. For example, during the July 2014 event, throughfall under the pine trees started after $40 \mathrm{~min}$ from the beginning of the event, simultaneously with a drop diameter increase, when $1.8 \mathrm{~mm}$ of rainfall fell as well [24].

The duration and rainfall distributions of events B and C were similar, as they were 69 and $71 \mathrm{~min}$ long, respectively, and the majority of rainfall was concentrated in the first $20 \mathrm{~min}$ of the events. However, event B delivered $15.2 \mathrm{~mm}$ of rainfall, and event C $33.4 \mathrm{~mm}$ of rainfall. Throughfall under the pine trees after the occurrence of larger and faster drops immediately increased in both cases, but it exceeded the amount of rainfall in the open only in the case of event B (Figure 4). A similar phenomenon was also reported for the June 2014 event, which was $75 \mathrm{~min}$ long and delivered $10.2 \mathrm{~mm}$ of rainfall [24]. This may be the consequence of the time delay in the increase in the drop size spectrum and the amount of rainfall delivered until then (Figures 4 and 5). For event $C$, during which throughfall under the pine trees remained lower than the rainfall in the open, an increase in the drop diameter and velocities was observed $4 \mathrm{~min}$ after the beginning of the rainfall event, when $2 \mathrm{~mm}$ of rainfall 
had fallen and the tree canopy was not yet fully saturated. To compare to other studies, water storage capacity estimated for coniferous trees ranges up to $2.7 \mathrm{~mm}$ for red pine [48] and up to $2.8 \mathrm{~mm}$ for sitka spruce canopy [49]. However, an increase in drop size distribution during event $B$ was observed after $13 \mathrm{~min}$, when $6 \mathrm{~mm}$ of rainfall had already fallen. Additionally, drop diameter and velocity increase during the June 2014 event occurred after $15 \mathrm{~min}$, when $4.6 \mathrm{~mm}$ of rainfall had fallen [24]. By that time, the canopy storage capacity was full. Nanko et al. [3] reported that the occurrence of larger and faster raindrops induces vibrations of the canopy, which is similar to wind stimulating dripping of stored water, and significantly increases throughfall, a fact which has also been reported by other authors $[3,13,38]$.

The increase in drop size and velocity spectrum influenced throughfall under the pine trees for each analysed event; however, no such response was observed for the birch trees. During all three considered events, the amount of throughfall under the birch trees maintained the same quantity from the start, and also when the rainfall began to decline. After that, the throughfall under the birch trees exceeded the rainfall in the open (Figures 3-5). Therefore, we can assume that the throughfall under the birch trees was the result of a saturated canopy, rather than the changes in drop diameter and velocity. The different response of pine and birch trees may be a result of different tree properties (Table 1). Nanko et al. [3] indicated that broad-leafed trees, such as sawtooth oak, have a larger water storage area per leaf than needle-leafed trees. Also, storage capacity of leaves was measured to be higher for larger drops than for smaller ones, as reported by other researchers $[4,50]$. Therefore, the birch tree (as a deciduous tree) retains larger drops on leaves, while pines react to drops with larger diameters with increased throughfall. Andre et al. [13] reported that larger canopy storage capacity is also related to larger leaf area index (LAI), which was higher for birch than for pine trees during the analysed events in our study (Table 1). Additionally, higher branch inclination increases throughfall, which is consistent with the results of Bassette and Bussiere [4], as birch tree branches are oriented towards the sky, while pine tree branches lean towards the ground (Table 1). Due to downwards branch inclination, intercepted rainfall may laterally translocate towards the canopy edge [51], which may lead to the occurrence of drip points where throughfall exceeds $100 \%[14,52,53]$. However, the lateral translocation of the captured rain seems not to have had a significant influence on throughfall under the pine trees in our study. Furthermore, the properties of branches and stem are important, as Llorens and Gallart [48] showed that the specific water retention capacity of branches and stem is six times higher than that of needles.

\section{Conclusions}

Continuous measurements of rainfall, throughfall, and drop size distribution (DSD) over three and a half years provided enough data to analyse the influence of open rainfall microstructure on throughfall. Similar to previous studies on interception, we showed that throughfall increases with the rainfall amount and duration. Additionally, rainfall distribution during the event influences the amount of throughfall. We demonstrated that an increase in drop diameter and velocity on the event scale is connected with an increase of throughfall under pine trees, whereas birch trees did not show any response. During event A, a $4 \%$ increase of average drop diameter and a $6 \%$ increase of average drop velocity increased throughfall under the pine trees by $32 \%$. Birch trees have different properties to pine trees, which probably determined their response to changes in DSD. Birch trees' larger leaf area index (LAI), upwards branch inclination, smooth bark, and finally, possession of leaves instead of needles, eliminated the effect of larger and faster raindrops. However, when the beginning of an event involved low intensity rainfall, the increase in drop velocity and diameter induced throughfall under both tree species. In comparison to events $B$ and $C$, the late start of throughfall in event $A$, triggered only by $1.2 \mathrm{~mm}$ of rainfall, was observed simultaneously as an increase in drop size distribution.

The results of this study indicate that rainfall microstructure is an important variable influencing throughfall dynamics. The differences in the response of these two distinct tree species suggest that future research on the influence of open rainfall DSD on the throughfall amount and dynamics is 
needed. This may help to understand how rainfall DSD in various climate zones influences throughfall dynamics, and how it is affected by different tree canopy characteristics.

Acknowledgments: The research was financially supported by the Slovenian Research Agency through the PhD grant of the first author (K. Zabret). The critical and useful comments of three anonymous reviewers improved this work, for which the authors are very grateful.

Author Contributions: K. Zabret, J. Rakovec and M. Šraj drafted the manuscript and determined the aims of the research; K. Zabret collected and analysed the data; M. Mikoš and J. Rakovec contributed to data interpretation; K. Zabret wrote the paper and with M. Šraj revised it.

Conflicts of Interest: The founding sponsors had no role in the design of the study; in the collection, analyses, or interpretation of data; in the writing of the manuscript, and in the decision to publish the results.

\section{References}

1. Brandt, C.J. The size distribution of throughfall drops under vegetation canopies. Catena 1989, 16, 507-524. [CrossRef]

2. Dunkerley, D. Measuring interception loss and canopy storage in dryland vegetation: A brief review and evaluation of available research strategies. Hydrol. Process. 2000, 14, 669-678. [CrossRef]

3. Nanko, K.; Hotta, N.; Suzuki, M. Evaluating the influence of canopy species and meteorological factors on throughfall drop size distribution. J. Hydrol. 2006, 329, 422-431. [CrossRef]

4. Bassette, C.; Bussiere, F. Partitioning of splash and storage during raindrop impacts on banana leaves. Agric. For. Meteorol. 2008, 148, 991-1004. [CrossRef]

5. Levia, D.F.; Hudson, S.A.; Llorens, P.; Nanko, K. Throughfall drop size distributions: A review and prospectus for future research. WIREs Water 2017, 4, e1225. [CrossRef]

6. Nanko, K.; Hudson, S.A.; Levia, D.F. Differences in throughfall drop size distributions in the presence and absence of foliage. Hydrol. Sci. J. 2016, 61, 620-627. [CrossRef]

7. Fleischbein, K.; Wilcke, W.; Goller, R.; Boy, J.; Valarezo, C.; Zech, W.; Knoblich, K. Rainfall interception in a lower montane forest in Ecuador: Effects of canopy properties. Hydrol. Process. 2005, 19, 1355-1371. [CrossRef]

8. Deguchi, A.; Hattoria, S.; Park, H. The influence of seasonal changes in canopy structure on interception loss: Application of the revised Gash model. J. Hydrol. 2006, 318, 80-102. [CrossRef]

9. Vilhar, U. Padavinski režim $\mathrm{v}$ izbranih vrzelih in sestojih dinarskega jelovo-bukovega gozda. Zbornik Gozdarstva in Lesarstva 2010, 91, 43-58. (In Slovenian)

10. Zabret, K. The influence of tree characteristics on rainfall interception. Acta Hydrotech. 2013, 26, 99-116. (In Slovenian)

11. Crockford, R.H.; Richardson, D.P. Partitioning of rainfall into throughfall, stemflow and interception: Effect of forest type, ground cover and climate. Hydrol. Process. 2000, 14, 2903-2920. [CrossRef]

12. Xiao, Q.; McPherson, E.G.; Ustin, S.L.; Grismer, M.E.; Simpson, J.R. Winter rainfall interception by two mature open-grown trees in Davis, California. Hydrol. Process. 2000, 14, 763-784. [CrossRef]

13. Andre, F.; Jonard, M.; Ponette, Q. Influence of species and rain event characteristics on stemflow volume in a temperate mixed oak-beech stand. Hydrol. Process. 2008, 22, 4455-4466. [CrossRef]

14. Šraj, M.; Brilly, M.; Mikoš, M. Rainfall interception by two deciduous Mediterranean forests of contrasting stature in Slovenia. Agric. For. Meteorol. 2008, 148, 121-134. [CrossRef]

15. Siegert, C.M.; Levia, D.F. Seasonal and meteorological effects on differential stemflow funneling ratios for two deciduous tree species. J. Hydrol. 2014, 519, 446-454. [CrossRef]

16. Uijlenhoet, R.; Sempere Torres, D. Measurement and parameterization of rainfall microstructure. J. Hydrol. 2006, 328, 1-7. [CrossRef]

17. Calder, I.R. Dependence of rainfall interception on drop size: 1 . Development of the two-layer stochastic model. J. Hydrol. 1996, 185, 363-378. [CrossRef]

18. Hall, R.L. Interception loss as a function of rainfall and forest types: Stochastic modelling for tropical canopies revisited. J. Hydrol. 2003, 280, 1-12. [CrossRef]

19. Frasson, R.; Krajewski, W. Characterization of the drop-size distribution and velocity-diameter relation of the throughfall under the maize canopy. Agric. For. Meteorol. 2011, 151, 1244-1251. [CrossRef] 
20. Fornis, R.L.; Vermeulen, H.R.; Nieuwenhuis, J.D. Kinetic energy-rainfall intensity relationship for Central Cebu, Philippines, for soil erosion studies. J. Hydrol. 2005, 300, 20-32. [CrossRef]

21. Petan, S.; Rusjan, S.; Vidmar, A.; Mikoš, M. The rainfall kinetic energy-intensity relationship for rainfall erosivity estimation in the Mediterranean part of Slovenia. J. Hydrol. 2010, 391, 314-321. [CrossRef]

22. Caracciolo, C.; Napoli, M.; Prodi, F. Raindrop Size Distribution and Soil Erosion. J. Irrig. Drain. Eng. 2012, 138, 461-469. [CrossRef]

23. Nanko, K.; Watanabe, A.; Hotta, N.; Suzuki, M. Physical interpretation of the difference in drop size distributions of leaf drips among tree species. Agric. For. Meteorol. 2013, 169, 74-84. [CrossRef]

24. Zabret, K.; Rakovec, J.; Šraj, M. Evaluation of Drop Size Distribution Impact on Rainfall Interception by Trees. Proceedings 2017, 1, 117.

25. ARSO. Available online: http://www.meteo.si/met/sl/archive/ (accessed on 9 August 2017).

26. Tapiador, F.J.; Checa, R.; de Castro, M. An experiment to measure the spatial variability of rain drop size distribution using sixteen laser disdrometers. Geophys. Res. Lett. 2010, 37, L16803. [CrossRef]

27. You, C.; Lee, D. Decadal Variation in Raindrop Size Distributions in Busan, Korea. Adv. Meteorol. 2015, 2015, 329327. [CrossRef]

28. Park, S.G.; Kim, H.; Ham, Y.; Jung, S. Comparative Evaluation of the OTT PARSIVEL Using a Collocated Two-Dimensional Video Disdrometer. J. Atmos. Ocean. Technol. 2017, 34, 2059-2082. [CrossRef]

29. Bruijnzeel, L.A. Forest Hydrology. In The Forestry Handbook; Evans, J.S., Ed.; Blackwell: Oxford, UK, 2000; Volume 1, Chapter 12, pp. 301-343.

30. Zimmermann, A.; Zimmermann, B. Requirements for throughfall monitoring: The roles of temporal scale and canopy complexity. Agric. For. Meteorol. 2014, 189-190, 125-139. [CrossRef]

31. OTT Hydromet. Operating Instructions. Present weather sensor OTT Parsivel. 2016. Available online: http:/ / www.ott.com/en-us/products/download/operating-instructions-present-weather-sensor-ottparsivel2/ (accessed on 8 November 2017).

32. Nanko, K.; Mizugaki, S.; Onda, Y. Estimation of soil splash detachment rates on the forest floor of an unmanaged Japanese cypress plantation based on field measurements of throughfall drop sizes and velocities. Catena 2008, 72, 348-361. [CrossRef]

33. Ciaccioni, A.; Bezak, N.; Rusjan, S. Analysis of rainfall erosivity using disdrometer data at two stations in central Slovenia. Acta Hydrotech. 2016, 29, 89-102.

34. Gunn, R.; Kinzer, G.D. The Terminal Fall Velocity for Water Droplets in Stagnant Air. J. Atmos. Sci. 1949, 6, 243-248. [CrossRef]

35. Livesley, S.J.; Baudinette, B.; Glover, D. Rainfall interception and stemflow by eucalypt street trees-The impacts of canopy density and bark type. Urban For. Urban Green. 2014, 13, 192-197. [CrossRef]

36. Šraj, M. Intercepted precipitation: Measurements and analysis. Geografski Vestnik 2008, 81, 99-111. (In Slovenian)

37. R Core Team. R: A language and environment for statistical computing. R Foundation for Statistical Computing 2015, Vienna, Austria. Available online: http:/ / www.R-project.org/ (accessed on 5 March 2015).

38. Xiao, Q.; McPherson, G. Rainfall interception of three trees in Oakland, California. Urban Ecosyst. 2011, 14, 755-769. [CrossRef]

39. Inkiläinen, N.M.; McHale, M.R.; Blank, G.B.; James, A.L.; Nikinmaa, E. The role of the residential urban forest in regulating throughfall: A case study in Raleigh, North Carolina, USA. Landsc. Urban Plan. 2013, 119, 91-103. [CrossRef]

40. Cape, J.N.; Brown, A.H.F.; Robertson, S.M.C.; Howson, G.; Paterson, I.S. Interspecies comparisons of throughfall and stemflow at tree sites in nothern Britain. For. Ecol. Manag. 1991, 46, 165-177. [CrossRef]

41. Buttle, J.M.; Farnsworth, A.G. Measurement and modeling of canopy water partitioning in a reforested landscape: The Ganaraska Forest, southern Ontario, Canada. J. Hydrol. 2012, 466-467, 103-144. [CrossRef]

42. Asadian, Y.; Weiler, M. A New Approach in Measuring Rainfall Interception by Urban Trees in Coastal British Columbia. Water Qual. Res. J. Can. 2009, 44, 16-25.

43. Staelens, J.; De Schrijver, A.; Verheyen, K.; Verhoest, N.E.C. Rainfall partitioning into throughfall, stemflow, and interception within a single beech (Fagus sylvatica L.) canopy: Influence of foliation, rain event characteristics, and meteorology. Hydrol. Process. 2008, 22, 33-45. [CrossRef]

44. Zabret, K.; Mikoš, M.; Rakovec, J.; Šraj, M. Proces prestrezanja padavin: Vpliv vegetacijske dobe, trajanja padavinskega dogodka ter mikrostrukture padavin. In Raziskave s Področja Geodezije in Geofizike 2015, 
Proceedings of the Redna Letna Skupščina SZGG, Ljubljana, Slovenia, 28 January 2016; Univerza v Ljubljani: Ljubljana, Slovenia, 2016.

45. Klaassen, W.; Bosveld, F.; de Water, E. Water storage and evaporation as constituents of rainfall interception. J. Hydrol. 1998, 212-213, 36-50. [CrossRef]

46. Calder, I.R.; Hall, R.L.; Rosier, P.T.W.; Bastable, H.G.; Prasanna, K.T. Dependence of rainfall interception on drop size: 2. Experimental determination of the wetting functions and two-layer stochastic model parameters for five tropical tree species. J. Hydrol. 1996, 185, 379-388. [CrossRef]

47. Hall, R.L.; Calder, I.R.; Nimal Gunawardena, E.R.; Rosier, P.T.W. Dependence of rainfall interception on drop size: 3. Implementation and comparative performance of the stochastic model using data from a tropical site in Sri Lanka. J. Hydrol. 1996, 185, 389-407. [CrossRef]

48. Llorens, P.; Gallart, F. A simplified method for forest water storage capacity measurement. J. Hydrol. 2000, 240, 131-144. [CrossRef]

49. Hutchings, N.J.; Milne, R.; Crowther, J.M. Canopy storage capacity and its vertical distribution in a Sitka spruce canopy. J. Hydrol. 1988, 104, 161-171. [CrossRef]

50. Keim, R.F.; Skaugset, A.E.; Weiler, M. Storage of water on vegetation under simulated rainfall of varying intensity. Adv. Water Resour. 2006, 29, 974-986. [CrossRef]

51. Frischbier, N.; Wagner, S. Detection, quantification and modelling of small-scale lateral translocation of throughfall in tree crowns of European beech (Fagus. sylvatica L.) and Norway spruce (Picea. abies (L.) Karst.). J. Hydrol. 2015, 522, 228-238. [CrossRef]

52. Gomez, J.A.; Vanderlinden, K.; Giraldez, J.V.; Fereres, E. Rainfall concentration under olive trees. Agric. Water Manag. 2002, 55, 53-70. [CrossRef]

53. Yousefi, S.; Sadeghi, S.H.; Mirzaee, S.; van der Ploeg, M.; Keesstra, S.; Cerdà, A. Spatio-temporal variation of throughfall in a hyrcanian plain forest stand in Northern Iran. J. Hydrol. Hydromech. 2018, 66, 97-106. [CrossRef]

(C) 2017 by the authors. Licensee MDPI, Basel, Switzerland. This article is an open access article distributed under the terms and conditions of the Creative Commons Attribution (CC BY) license (http:/ / creativecommons.org/licenses/by/4.0/). 